\title{
Appointing and Removing Academic Staff in Public Institutions: The Level of Autonomy at Kyambogo University, Uganda
}

\author{
Ayebare Justin ${ }^{1}$, Kisige Abdu ${ }^{1}$, Gitta Eric ${ }^{1}$, Betihamah Jackson ${ }^{1} \&$ Kimoga Joseph ${ }^{1}$ \\ ${ }^{1}$ College of Education and External Studies, Makerere University, Kampala, Uganda \\ Correspondence: Ayebare Justin, College of Education and External Studies, Makerere University, Kampala, \\ Uganda.
}

Received: September 27, 2016

Accepted: October 18, 2016

Online Published: March 16, 2017

doi:10.5430/irhe.v2n 1p101

URL: https://doi.org/10.5430/irhe.v2n1p101

\begin{abstract}
Many governments, the university sector and the European Commission have recognized that increasing university autonomy represents a crucial step towards modernizing higher education in the 21 st century. This study which was conducted at Kyambogo University highlights that in practice, public authorities still play a central role in the regulation of higher education systems more especially in the appointment and dismissal of academic staff. Despite the fact that the ministry has moved away from direct state control towards more "indirect" steering mechanis ms, universities often continue to lack autonomy in many crucial areas, particularly in terms of filling staff positions. The purpose of this study therefore was to establish the level of institutional autonomy in academic staff appointment and removal at Kyambogo University. The researchers analysed each dimension of university autonomy in terms of appointment and dismissal of academic staff. We found out that appointment and removal of the academic staff in Kyambogo University was not in line with what is provided for in the Human Resource Manual and national guiding Acts, Laws and Standing orders. We recommend that since universities have a unique duty to perform that requires specific skilled staff, they should be given autonomy in the appointment and removal of these staff.
\end{abstract}

Keywords: institutional autonomy, appointment, removal, academic staff

\section{Introduction}

Although in many countries, industry is invited to fund research labs, professorships and joint research projects, and students contribute towards the costs of teaching through paying fees, Universities all over the world are still widely considered to be part of the public sector (Wright \& Rabo, 2010). Indeed, in public or state owned universities, decisions are in most cases influenced by the state which makes the appointment and removal of academic staff become part of the established structure of the government. Academic staff are an important component of an education institution (Government of Uganda [Go U], 1992; Kasozi, 2009; Kyvik, 2013; Mamdan, 2007). Their presence enhances the teaching, research and service profile of the institution and contributes to the intellectual life of the University and to the economy at large (Altbach \& Salmi, 2011). Without the productive effort of these, the materials and other services would be rendered useless. It may be desirable especially for recurrent academic staff to be recognized through a formal University appointment and removal procedure. While a first class university consists of first class academic staff who understand the purpose for which their institution exists and agree to implement its mission, their appointment and re moval has to be formal and acceptable. In most universities however, the principle in accord with which this formal appointment and removal structure of these academic staff has not been explicit. It appears the whole university system has been politicized due to the erosion of autonomy especially in public universities (GoU, 2010). The purpose of this study therefore is to examine how realistic the attainment of full autonomy in appointment and removal of academic staff is in a public univers ity like Kyambogo University.

\section{Literature Review}

In Uganda, higher education, and particularly university education is recognized as a key force for modernization and development (Adewale, 2014). However, for higher education to be able to do this there is need for well-qualified and appointed academic staff. Ajayi (2013) argues that given their pivotal position, academic staff in institutions of higher learning plays an important role in the execution of institutional objectives. The lecturer as the greatest aid to learn ing is the most important instrument in the academic system; the direct personal contact between learner and the teacher remain the linchpin of the educational process. Like wise, Nicol (2012) asserts that the 
planning of a teacher requirement and supply becomes the central concern in the development and smooth functioning of any educational institution that needs to provide good quality education. Accordingly, the staffing of higher education, therefore, has a lot to do with the quality of education a university offers. For universities to attract and appoint well trained and competent academic staff there is need for some institutional autonomy; without interference from the state or other agencies; where the university sets its own objectives and manages its own affairs (Horn, 2010).

Autonomy is a multidimensional concept that appears in the use of many autonomy related concepts and various dimensions within the same concept (Kohtamaki, 2009). Institutional autonomy is a concept with contes ted meaning in contemporary higher education literature (Ya'u, 2014). Ya'u argued that 'university autonomy may be understood to mean freedom granted to each university to manage its internal affairs without undue interference from outside bodies, persons, or, most especially, from the government. Institutional autonomy according to Organization for Economic Cooperation and Development (OECD) (2013) implies: (a) the freedom of universities to select their students and staff by criteria chosen by the universities themselves; (b) autonomy to shape their curriculum and syllabus, and (c) the freedom to decide how to allocate among their various activities, such funds made available to them. Generally, institutional autonomy relates to considerable freedom to determine their o wn policies and priorities in a wide range of their institutional activities.

In the case of this study, institutional autonomy relates to the corporate freedom of an institution in selecting, appointing, and dismissal of academic staff. As part of its autonomy, an education institution must have freedom to run its own affairs relating to staffing, without external interference; it must have the right to organize its internal affairs, to make decisions, and to establish its own academic progra ms (Horn, 2010). Kayode (2008) observes that autonomy is a condition of effective self-government for institutional realization of its objectives.

According to the Ugandan Public Service Standing Orders (GoU, 2010), appointment refers to an offer to a pers on of a job or position of responsibility in the public service; including promotion from one public office to another, or transfer from one public office to another. In other words appointment is the act of giving a particular job or position to someone, placing, or appointing someone into an unelected position.

The term academic staff is defined as academic professionals who are responsible for planning, directing, and undertaking academic teaching and research within higher education institutions (Kyambogo University, 2014). In higher education institutions, academic staff is engaged in teaching, research, and outreach to the community in line with institutional mission (GoU, 1992). In public universities in Uganda, the academic staff include Principals of colleges, Deans or Directors of faculties/schools/institutes, professor emeritus, professors, associate professors, senior lecturers, lecturers, assistant lecturers, teaching assistants, research fellows, research assistants, and library staff Human Resource Manual (Kyambogo University, 2014; Universities and Other Tertiary Institutions Act, 2001; National Council for Higher Education [NCHE] (Go U, 2011). Removal is the act of moving or taking something away from a place; the act of making something go away so that it no longer exists; an act of forcing someone to leave a job. Similarly, Panty (2015) defined removal as the act of taking something or someone away from somewhere or something.

According to Estermann and Steinel (2011), there is a broad agreement between stakeholders that institutional autonomy is important for modern universities to achieve their mission in the best possible way. Studies indicate that increasing institutional autonomy is a key to capacitate universities to respond to the challenges in an increasingly comple $x$ and global environ ment (Estermann, Nokkala, Steinel, 2009). Institutional autonomy helps to create quality. This view is also supported by Rerchet and Tauch (2005) who observed that there is clear evidence that success in improving quality within the institution is directly correlated with the degree of institutional autonomy.

While recruiting, Cole (2002) affirms that institutions need to know how many people and what sort or type of people they should have to meet present and future institutional requirements. Although inadequacy of recruitment was cited in many higher education institutions as the reason why today they are facing chaotic situations, there is no proper planning for their workforce, neither do they have any systematic well implemented human resource management programme that puts the institutional goals first (Anyadike, 2013). Burney \& Widener (2013) add that the cause of this unfortunate development is heavily a lack of human resource planning. However, Ky ambogo and other public higher education institutions in Uganda developed human resource management manuals that guide the planning, operations and management of human resources and constitute the terms and conditions of service for all categories of employees in the University. This is in realization of what Graf (2007) proposed as the aim of a human resource strategy which is to ensure that a firm achieves competitive advantage by attracting and retaining more capable staff than its rivals and employing them more effectively. In brief, Cole (2002) puts it that the organization 
deploys its people in ways that maximize the added value they create. Armstrong (2009) describes the entire process as using a systematic approach, starting with human resource planning and proceeding through recruit ment, selection, appointment and induction, followed by performance management, learning and development, recognition and reward.

The recruitment process must signal that the University values diversity and is an equal op portunities employer within the criteria of a given appointment (Kayode, 2010). Appointments are made on competitive terms, and the University ensures that the duties entailed by the position may be organized so as to strike a balance between work commitments and working hours and between work and leisure. Therefore, Cole (2002) advises that human resource planning is the most essential element for industrial productivity that goes through recruitment, selection and appointment.

In order to satisfy this objective Nyamupachari (2011) advises that human resource managers must develop plans to find employees with special skills, attract them to the company, select the best candidates, train them, reward them competitively, etc. Anyadike (2013) adds that just as companies must plan ahead to ensure a steady supply of raw materials, machinery and office space, higher Education institutions must also plan ahead to maintain a steady supply and to acquire quality employees.

The freedom to recruit and set salary levels for academic and administrative staff was positively linked to performance (OECD, 2013). The report added that in the 20th century in most OECD countries, it was realized that governments exercised considerable control and influence over all sectors including education sector, to help pursue objectives such as economic growth and social equity. However today, governments have a greater interest than ever in ensuring that educational institutions help meet economic and social needs, given their importance in knowledge-creation in the knowledge oriented societies. In some countries, however, universities are gaining greater flexibility in dealing with staffing issues, as the staffs are being paid and/or employed directly by the university rather than by the government. However, the decisions on salaries are still to a large degree controlled by the government. The same OECD (2013) found out that in Japan, France, Korea, and Switzerland, governments had an upper hand in the appointment of acade mic staff, fulltime faculty members and senate. This is a manifestation of lack of institutional autonomy in staffing. Similarly, Aghion et al., (2008) found out that universities in high performing countries do not typically enjoy some level of autonomy whether in hiring or in job setting.

According to Graf (2007), recru itment as the first stage in the process of filling a vacancy involved the examination of requirements for filling the vacancy. The search considers good reputation experience and proven track record, due diligence and referrals especially from reputable scholars, senior executives and all these are subjected to the selection process of appointments board.

\section{The Policy}

The policy of appointing academic staff in Uganda according to the Universities and Other Tertiary Institutions Act (GoU, 2001) number 52 states that academic staff shall be appointed by the University Appointments Board on terms and conditions that may be determined by the University Council in respect of each category of staff. In this respect, the offer of appointment is made in writing by the Director Human Resources and copies are sent to faculty deans and heads of departments (Kyambogo University, 2014).

Article 172 (1) (a) of the constitution of the Republic of Uganda, clearly indic ates that the President may, acting in accordance with the advice of the Public Service Commission and the Education Service Commission or as the case may be, appoint persons to hold or act in any office in the public service of Uganda of the rank of Head of Department or above including confirmation of appointments, the exercise of disciplinary control over such persons and their removal from office; (3) Subject to the provisions of this Constitution, the President may delegate any of his or her powers under this article directions in writing, to any service commission or to any other authority or public officer as may be prescribed by Parliament and may, in like manner, revoke the delegation. However in public Higher Education, the University Council is respons ible for all appoint ments through the appointments Board except the positions of the Vice Chancellor, Deputy Vice Chancellors and principals who are directly appointed by the Council.

It is worth considering that employees in Public Higher Education Institutions are public officers who serve in public offices and whose emoluments are taken from Government consolidated funds. They should abide by the standing orders of Ugandan Public Service (GoU, 2010). A though the standing orders on public service are silent on principals underpinning the recruitment and selection process, Higher Education, institutions state in their recruitment and selection policy that, the University is a single employer and will implement appropriate search and 
recruitment strategies to appoint high calibre staff who meet the job requirements of the vacant position (GoU, 2010; Kyambogo University, 2014).

In general, the literature cited here in indicates that for any University to meet its core functions (teaching, research and community outreach), it must have the capacity to exercise its powers in appointing and removing the academic staff. However the level of autonomy in the reviewed literature concentrated on planning for human resource and remained silent on other factors that affect autonomy in regards to appointment and removal of academic staff in Universities. This study therefore attempts to highlight on such factors.

\section{Stating the Case}

This study was carried out at Kyambogo University to ascertain the level of institutional au tonomy in relation to appointment and removal of academic staff. Kyambogo University came into existence in 2003 as a result of a merger of the three former Institutions namely; Kyambogo Polytechnic, Institute of Teachers Education Kyambogo, (ITEK) and Uganda National Institute of Special Needs Education (UNISE). The merger occurred after a recommendation of parliament with the Statutory instrument by Parliament of Uganda in line with the Universities and other Tertiary Institutions Act (GoU, 2001) as amended in 2003 and 2006. The core functions of the Public Universities, Kyambogo inclusive as per this Act are; teaching, research and consultancy or commun ity engagement. Therefore, the academic heartland of a University includes the academic staffs, who are one of the major stakeholders in the human resource endowment, for it to fulfil core functions of the university (Nicol, 2012).

The Ugandan Public Standing Orders (Go U, 2010) and the Public Service Act (Go U, 2008b), assert that subject to the provision of the constitution, the minister of public service shall have authority for overall management and administration of public service including formulation and review of policies relating to structures, management systems and the terms and conditions of service. This means that the min ister of public service has the legal mandate to influence the appointment of academic staff since he can cause policy review to the terms and conditions.

Removal of academic staff at Kyambogo University can arise out of breach of contract or as stipulated in the provisions for termination of service in Human Resource Manual (Kyambogo University, 2014). The provisions aim to ensure that the university is in line with good employment practice and comply with the statutory requiremen ts. Staff can be removed from office normally at the expiration of tenure, retirement, redundancy, or by dismissal due to serious cases of ethical and professional misconduct, absconding or abandonment of duty, criminal conviction and acting in a way incompatible with his or her status as a public officer.

Institutional autonomy is crucial if an education institution is to recruit and hire well qualified and competent staff (Ajayi, 2013). Although the Universities and Other Tertiary Institutions Act (GoU, 2001) gives the university council as the appointment committee a mandate to appoint university staff on terms and conditions that may be determined by the university council. In respect to each category of staff, the Hu man Resources Manual (Kyambogo Unive rsity, 2014) provides for institutional autonomy in appointing and removal of academic staff under the guidance of university council. With such autonomy, there are many complaints of government and government official's interference which hinders institutional staffing and performance (Tumwebaze, 2014). Similarly a report by the Auditor General (GoU, 2014) on Kyambogo University staffing levels revealed that the Institution is understaffed just with $30 \%$ of the total staff establishment and $70 \%$ of the teach ing staff are part-timers who are paid on part time basis. This was due to the restrictions on recruitment in public service and thus a ban on appointment of more academic staff that affected almost all public education institutions since 1998. The situation according to Tumwebaze (2014) affected institutional performance as lack of appointment of required staff overstrained the few appointed academic staff, hence affecting the university and staff performance. As such, a study into institutional autonomy in appointment and removal of academic staff at Kyambogo University can throw some light on the situation.

\section{Theoretical Consideration}

Institutional autonomy is a function of the degree to which sets of specialized corporate actors are structurally and symbolically independent of other sets of corporate actors. The study will be guided by the institutional theory developed by Meyer and Rowan (1977). Rationale for this theory is based on the reality that organizations do not exist in a vacuum but interact with their environment to achieve their objectives (Leisyte, 2011). The theory states that institutions are guided by regulatory, social and culture differences that promote survival and legitimacy of an organization rather than focusing solely on efficiency-seeking behaviour. The second assumption of the theory is that it represents models of organizational and individual behaviours based on obligation dimensions, social, professional 
and organization interaction. Institutional theory emphasizes the final value of organizational conformity to institutional environment (Gorntzka, 1999).

Institutions therefore guide behaviour by defining what is appropriate or expected in the various social and commercial situations. According to this theory, adaption of policies or programs is primarily determined by the extent to which the measure is institutionalized whether by law or by gradual legitimation (Nicol, 2012). Basing on the theory, aspects of institutional autonomy regarding appointment and dismissal of academic staff in Kyambogo University can be explained using regulatory, social, cultural differences that promote legitimacy within the university. However, failure to exerc ise freedom in appointment and removal of academic staff would tantamount to failure to exercise institutional autonomy and consequently failure to achieve intended goals and objectives.

\section{Methodol ogy}

The study adopted a descriptive case study design. It described situations and events in respect to interconnectedness between institutional autonomy and staff appointment and removal in institutions of higher learning. It was a case study as it zeroed on Kyambogo University and concentrated on in depth understanding of how the national appointment frameworks and policy documents influence process es and procedures of staffing. This study provided findings drawn predominantly from the qualitative content analysis of data collected from both primary and secondary documents belonging to the institution and government. National legal frame works like the constitution of Uganda (Go U, 1995) and Public Standing Orders (GoU, 2010), Public Service Act (GoU, 2008b), Hu man Resource Manual (Kyambogo University, 2014), the Inspector General of Government [IGG] report (2015), and the Auditor General (AG) report (GoU, 2014) on Kyambogo University were reviewed. This approach was regarded as genuine and relevant for this study as it intended to interpret in depth the available authentic documents.

\section{Findings}

The study revealed that appointment and removal of the academic staff in Kyambogo University was not in line with what is provided for in the Human Resource Manual (Kyambogo University, 2014). It was revealed that in most cases, there was a deviation from what the national documents, Acts, Laws on higher education like the Universities and Other Tertiary Institutions Act (GoU, 2001), Government Standing Orders (GoU, 2010) state.

\section{Appointment}

The Inspector General of Government's report [IGG] (Go U, 2015) highlights that the highest academic staff are at the level of Professor and the lowest at the level of Masters. The Human Resource manual (Kyambogo University, 2014) states that, "given that having continuity can be beneficial to the operation of the university, internal candidates with the relevant technical expertise and experience shall be recommended by management for consideration by the Appointment Board when the position falls vacant". This gives chance for internal promotions. In addition, for other candidates not within the university, appointment shall be through an external advert. However, due to the staffing levels of Kyambogo University where many lecturers had master's degree and below in the former institutions (Institute of teacher Education Kyambogo, Uganda polytechnic Kyambogo and the Uganda National Institute of Special Needs Education) that merged in 2003, the Human resources manual has not benefited many. Learning from the IGG (GoU, 2015), it was always difficult to get lecturers with PhDs to seek for promotions; and also difficult for Professors to occupy high profile positions especially whe re the majority teaching staffs are part timers, thus not internal me mbers. For example, the intention of the language department to recruit a professor failed to attract any candidate at all from within Kya mbogo and other universities in Uganda yet may be, there could have been capable ones at lower ranks. The university therefore, is limited in recruiting staff beyond the Human Resource stipulations, a policy by the university council to date.

Unlike the norms of the Universities and Other Tertiary Institutions Act (GoU, 2001), members of the current academic staff in Kyambogo University have different categories where majority are part timers (70\%) yet the public service standing orders (Go U, 2010) clarify that University employees are full time employees. In addition such part time staffs are paid according to the time worked (Kyambogo University, 2014). However the IGG's report (Go U, 2014) and Auditor General's report [AG] (GoU, 2014) found out that some academic staff part timers are remunerated monthly in ranges of M3, M4, and M5 salary scales which are supposed to be paid to full time staff. This could be due to reasons such as attracting more resourceful persons employed elsewhere to teach part -timely in Kyambogo University. However, being a public institution, this was taken as misallocating public funds, implying institutional limitedness in that line (GoU, 2014).

Lastly, the findings incriminated university administration for not sticking to the set recruitment and appointment levels which provide for university lecturers to be PhD holders only ranked from lecturer to Professor. The 
implication is that many academic members of staff were not qualified for the jobs. The issue to note here is that the university did not have mandate and freedom to recruit expert staff although not with required academic credentials.

\section{Removal}

The IGG's report (GoU, 2015) indicated some anomalies in removing academic staff from office at Kyambogo University not being in accordance to the Human Resource Manual (Kyambogo University, 2014), the higher education law, such as the Universities and Other Tertiary Institutions Act (GoU, 2001) as amended; and Government Standing Orders (Go U, 2001). A case in point is when the Vice Chancellor and his colleagues were forced to leave the university by some group of university staff who connived with other university admin istrators. Despite staff dissatisfaction with the Vice Chancellor and colleagues' leadership misconduct, university me mbers should have put up with the uncomfortable situation and follow proper procedures of removing their leaders from office.

In addition, the Ugandan public service standing orders (2010) and Public Service Act (GoU, 2008b) asserts that subject to the provisions of the constitution, the minister of public service shall have authority for overall management and administration of public service including formulation and review policies relating to structures, manage ment systems and the terms and conditions of service. This meant that the Minister of Public Service has the legal mandate to influence the removal of the academic staff since this minister can cause the policy review to the terms and conditions. When the choice of a candidate is made and before offering the appointment, the Human Resource manual (Kyambogo University, 2014) gives that chance for reference check on the candidate as a final process by the appointment. Where a candidate is found to have provided false information or misrepresented any information or not disclosed any material facts in his or her application, it shall be deemed to be sufficient ground for the university to withdraw the offer or terminate his /her service summarily as the case may be.

Similarly, the offences punishable by dismissal at Kyambogo University include; absconding or abandonment of duty; serious misconduct; professional or ethical misconduct; criminal conviction as per the manual and however much serious the nature of the situation the university adopts the disciplinary procedure with in the same manual for dismissal of staff which may include suspension, fair hearing and appearing before the disciplinary committee or appointment board among others.

Nevertheless the academic staff at Kyambogo University can be removed from office on expiry of the contract. The current Human Resources states that on expiry of the contract of employee, the university shall terminate the employment contract in case the employee on does not inform the appointments board in writing of intentions to renew h is contract shall be deemed to have lapsed up on expiry". There fore in Kyambogo University most academic staff that do not renew their recommended contracts are removed from office and others whose mandatory contracts expire, face exit without question.

Redundancy was also identified as a step to removal of academic staff in Kyambogo University where the requirements of the activity for the employee to carry out work in a particular kind have ceased /diminished or expected to cease/diminish. The employer makes arrangements for termination of services in consultation with the workers union as stipulated in the employment Act in force. This was observed in 2003 at the time of the merger of the three institutions of Institute of teachers' Kyambogo, Uganda Polytechnic Kyambogo and Uganda National Institute of Special Needs Education (UNISE) where most employees who did not match with the University standards were either retired or transferred to the Ministry of Education for re-deployment in line sectors.

Finally Removal of academic staff at Kyambogo University can arise out of breach of contract or as stipulated in chapter a line that gives provisions for termination of service in Human Resource Manual (Kyambogo University, 2014: 64) as it states "This policy sets out the conditional and procedures relating to termination of emp loy ment with Kyambogo University. It aims to ensure that the university is in line with good employment practice and comply with the statutory requirements". According to the Human Resource Manual, the staff can be removed from office by dismissal at it states that" An employee of the university can be dismissed in the most serious cases of misconduct and acting in a way incompatible with his or her status as a public officer".

\section{Discussion}

The study set out to study the level of institutional autonomy in academic staff appointment and removal at Kyambogo University. According to the findings, staffing and removal at Kyambogo University to some extent didn't follow what is stipulated in institutional policies and laws of higher education (Go U, 1995); Public Service Standing Orders (GoU, 2010); Public Service Act (GoU, 2008); Universities and Other Tertiary Institutions Act (GoU, 2001); Human Resource Manual (Kyambogo University, 2014) as researches done elsewhere have similarly noted. 


\section{Appointment}

The recruitment process must signal that the University values diversity and is an equal opportunities employer within the criteria of a given appointment (Kayode, 2010). While recruiting then, Cole (2002) observed that institutions need to know how many people and what sort or type of people they should have to meet the present and future business requirements. Although the inadequacy of recruitment was cited in many higher education institutions as the reason why today they are facing chaotic situations, there is no proper planning for their workforce, neither do they have any systematic well implemented human resource management programme that puts the institutional goals first (Anyadike, 2013). Burney and Widener (2013) could also be in agreement by arguing that the cause of this unfortunate development is heavily a lack of human resource planning, if not, what else could explain the sharp increase in workers strength as soon as any new chief executive emerges? This could not relatively be true as most public higher education institutions including Kyambogo University developed human resource management manuals that guide the planning, operations and management of human resources and constitute the terms and conditions of service for all categories of employees in the University. This can be supported by Graf (2007) who proposed that the aim of a human resource strategy is to ensure that a firm achieves competitive advantage by attracting and retaining more capable staff than its rivals and employ ing them more effectively. W ith this Cole (2002) agrees that the organization deploys its people in ways that maximize the added value they create. Yet Armstrong (2009) describes it as using a systematic approach, starting with human resource planning and proceeding through recruitment, selection, appointment and induction, followed by performance management, learning and development, recognition and reward.

What is taking place at Kyambogo University in the recruitment process greatly contradicts advice and standards given by Nyamupachari (2011) that human resource managers must develop plans to find employees with special skills, attract them to the company, select the best candidates, train them, and reward them competitively. The practice also is far from Anyadike's (2013) argument that companies must plan ahead to ensure a steady supply of raw materials, machinery and office space because available reports on Kyambogo university show the opposite of this.

In some cases however, what is happening at Kyambogo University is similar to what is taking place elsewhere in the some other countries. Sometimes, Kyambogo university admin istration fail to recruit needed academic staff due to government interest that must be followed even when applicants with required qualifications are not available. It is due to this government interference that the university has failed to attract competent, motivated and well qualified academic staff.

\section{Removal}

In a study conducted on public universities by $\operatorname{OECD}(2013)$ on member countries, it was found out that in Japan, France, Korea, and Switzerland, governments had an upper hand in the removal of academic staff, faculty members and senate. This is a manifestation of lack of institutional autonomy in staffing. Similarly, another study done by Malherbe (2008) on academic freedom and performance found out those universities in Africa do not typically enjoy some level of autonomy whether in hiring or dismissal of its staff. However what is happening in Kyambogo University could be administrators' influence in academic staff removal which was against the provision of the University and Other Tertiary Institutions Act (Go U, 2001) that gives guidelines and procedures on removal of staff (Tumwebaze, 2014).

According to Hart (2001), in parties where there are formal rules for leadership selection, no group could claim legitimate authority to remove a leader. This emphasized limited institutional autonomy in reacting to iss ues that need quick decisions to prevent serious consequences. Whereas there is clear guideline on procedures of how staff could be removed from office and termination of service (Kyambogo University, 2014), findings indicate that academic staff at Kyambogo University have been removed from office basing on personal and other reasons. This is exemplified by the unceremonious way in which the vice chancellor was ousted out of office without respecting any of the guiding laws. Several such anomalies were prevalent in the IGG report (Go U, 2015), and the employ ment and payment of unqualified staff.

\section{Conclusion}

\section{Appointment}

Significant increases in accountability measures have frequently curtailed university autonomy on appointing academic staff, highlighting the importance of striking a balance between institutional freedom and adequate accountability tools. The analysis in the findings showed that there are significant differences in the recruitment and appointment of staff in Kyambogo University ranging from a considerable degree of freedom to formalized 
procedures that entail an external approval, sometimes by the country's highest authorities (Tumwebaze, 2014). Although this may be a formality in some cases, it nevertheless impacts on the length of the recruitment and appointment procedure and therefore on the ability to act quickly in a competitive and increasingly international recruitment environment. The study concludes therefore that government interference in institutional decisions is a major setback to the achievement of considerable autonomy in Ugandan universities.

Removal

Using findings from the study, it can be concluded that although procedures for removal from office of academic staff is clearly stipulated in the Human Resource Manual, where one can leave office by resignation, dismissal, retirement, redundancy, expiry of contract among others it has not been properly managed (Go U, 2014). This has largely affected other dimensions of autonomy, such as organizational staffing and academic autonomy. There remains a frequent gap between formal institutional procedures "on paper" and a university's actual practices and ability to act independently in the removal of academic staff from their positions.

\section{Recommendations}

Based on the findings from the study, it is recommended that Institutions of higher learning in Uganda and Kyambogo in particular should be given the autonomy to select their staff through the university appointments board and determine the content of courses. This is in consonance with Govern ment earlier commitment that government shall continue to respect this freedom as long as these areas are in resonance with national goals (GoU, 1992). However, Universities should improve their accountability measure to ensure that university autonomy is not abused since it is expected to reinforce a balance between institutional freedom and accountability.

It is also recommended that staff removal procedures should follow stated procedural guidelines in the human resources manual if universities are to command trust and commitment from academic staff. Also government intervention should be reduced. In this regard therefore, there is a need to amend this aspect in the Universities and Other Tertiary Act (GoU, 2001) so that universities will be able to achieve the goals for which they have been established through full self-governance.

\section{References}

Adewale, E. T. (2014). The regulatory bodies, academic freedom and institutional Autonomy in Africa. Issues and Challenges-Nigerian Example, Nigeria.

Aghion, P., Dewatripont, M., Hoxby, C., Mas-Colell, A., \& Sapir, A. (2008). Higher Aspirations: An Agenda for Reforming European Universities. Bruegel blueprint 5, July 2008. Bruegel. Retrieved from http://EconPapers.repec.org/RePEc:ulb:ulbeco:2013/174284

Ajayi, J. F. (2013). Academic freedom and University autonomy in Nigeria today: A Historical survey and a search for new strategies. A Lecture delivered at the academic staff union of Universities Conference in Kano.

Altbach, P. G., \& Salmi, J. (Eds.). (2011). The road to academic excellence: The making of world-class research universities. World Bank Publications. http://dx.doi.org/10.1596/978-0-8213-8805-1

Anyadike, N. O. (2013). Hu man res ource planning and employee productivity in Nigeria public organization. Global Journal of Human Resource Management, 1(4), 56-68.

Armstrong, M. (2009). Handbook of Performance Management: An Evidence-Based Guide toDelivering High Performance (4th ed.). Kogan Page.

Burney, L. L., \& Widener, K. S. (2013). Behavioral work outcomes of a strategic performance measurement system-based incentive plan. Behavioral research in accounting, Fall, 25(2), 115-143. https://doi.org/10.2308/bria-50501

Cole, G. A. (2002). Personnel and Human Resource Management (5th ed.). Cengage Learning EMEA.

Esterman, T., \& Steinel, M. (2011). University autonomy in Europe. European University Association, Europe.

Esterman, T., Nokkala, T., \& Steinel, M. (2009). University autonomy in Eu rope; the scare card. European University Association, Europe.

Goetz, B. E. (1989). Management Planning and Control. New York: McGraw Hill Book Company.

Go rnitzka, Å. (1999). Govern mental policies and organis ational change in higher education. Higher Education, 38(1), 5-31. http://dx.doi.org/10.1023/A:1003703214848

Govern ment of Uganda. (1992). The Uganda White Paper on Education. Ministry of education, Uganda. Retrieved from www.education.go.ug 
Government of Uganda. (1995). The constitution of Republic of Uganda, Kampala, Uganda.

Government of Uganda. (2001). The Universities and other tertiary institutions act. Ministry of education, Uganda, Kampala. Retrieved from www.unche.or.ug

Government of Uganda. (2008). The Public Service Act. Ministry of public service, Uganda, Kampala. Retrieved from www.psc.go.ug

Government of Uganda. (2010). Instructions to the use of the public standing Orders, edition xiv - xvi. Ministry of Public Service, Uganda, Kampala. Retrieved from www.psc.go.ug

Government of Uganda. (2011). Quality assurance framework for universities and the licensing process for higher education institutions. NCHE, Kyambogo, Uganda. Retrieved from www.unche.or.ug

Government of Uganda. (2014). Auditor General report on Kyambogo University, Kyambogo.

Government of Uganda. (2015). Inspector General of Government report on the mismanagement of Kyambogo University.

Graf, A. (2007). Changing roles of customers: Consequences of HRM. St. Gallen: University of St. Gallen.

Horn, P. (2010). Academic Freedom within the University. The Eleventh EG Malherbe Academic Freedom Lecture delivered at the University of Natal on (2nd August 1978).

Kasozi A.B.K. (2009). Funding Uganda's public universities. An obstacle to serving the public good. Kampala Fountain.

Kayode, E. (2010). Thoughts on Human Rights and Education. A Freedom Lecture delivered at the University of Natal on (2nd August 1978), St Paul's Publishers, Ibadan.

Kohtamäki, V. (2009). Financial Autonomy in Higher Education Institutions-Perspectives of Senior Management of Finnish AMK Institutions. Tampereen yliopisto.

Kyambogo University. (2014). A manual that documents policies, procedures and guidelines for the management of human resources and moderating the behavior of employees of Kyambogo University. Approved by the University Council $-6^{\text {th }}$ November 2014.

Kyvik, S. (2013). The academic researcher's role: enhancing expectations and improved performance. Higher Education, 65(4), 525-538. http://dx.doi:10.1007/s 10734-012-9561-0

Leistyte, L. (2011). University commercialization policies and their implementation in Netherlands and United States. Science and Public policy, 38(6), 437-448. https://doi.org/10.3152/030234211X12960315267778

Malherbe, R. (2008). The Relationship between the State and Higher Education: Is sues of Centralization, Academic Freedom, University Autonomy and Accountability. A Paper Prepared for Higher Education South Africa, 18 June 2008.

Mamdani, M. (2007). Scholars in the Marketplace. Kampala: Fountain Publishers.

Meyer, J. W., \& Rowan, B. (1977). Institutionalized organizations: Formal structure as myth and ceremony. American Journal of Sociology, 340-363. Retrieved from http://www.jstor.org/stable/2778293

Nicol, D. (2012). Academic Freedom and Social Responsibility. In Stephen D. Kertesz (Ed.), The Task of Universities in a Changing World. Notre Dame University Press, Notre Dame.

Nyamupachari, V. A. (2011). Human resource management. Recruitment and performance. The case of European University Cyprus. Middlesex University.

OECD. (2013). Changing pattern of Governance in higher education. Educational Policy Analysis.

Panty, A. (2015). Cambridge English Dictionary. Cambridge University Press.

Reichert, S., \& Tauch, C. (2005). Trends IV: European Universities Implementing Bolgna. European Universities Association, Brussels.

Tumwebaze, R. (2014). The non-ending crisis in Kyambogo University. New Vision, October 17, 2014.

Wright, S., \& Rabo, A. (2010). Introduction: Anthropologies of university reform. Social Anthropology, 18(1), 1-14. http://doi/10.1111/j.1469-8676.2009.00096.x

Ya'u, Y. Z. (2014). Academic Staff Union of Universities under Attairu Jega: A Leadership Profile. Centre for Social Science Research \& Development, Lagos, 2004. 